\title{
Russian Arctic Policy, Petroleum Resources Development and the EU: Cooperation or Coming Confrontation?
}

\author{
Tina Hunter
}

$\mathbf{1}$ Introduction

The Arctic is a place of immense natural resource wealth, both onshore and offshore. ${ }^{1}$ Yet it is also an environment with extreme conditions, therefore presenting particular challenges to the development of the resources, especially offshore oil and gas resources. ${ }^{2}$ Whilst the melting of the Arctic sea ice poses a significant opportunity for the development of these resources (and the focus at present is the offshore oil and gas resources), the technical and environmental aspects of an operation, combined with the high costs, make such exploitation of resources difficult. However, as sea ice recedes, and technologies improve, there has never been a more opportune time to develop such resources. Such a coalescence of conditions has meant that some of the Arctic States, ${ }^{3}$ as well as other States with an interest in these vast resources, ${ }^{4}$ are seeking to develop them and advance national interests. In particular, the exploration of

* Tina Hunter, Professor, School of Law, University of Aberdeen, United Kingdom.

1 The USEIA estimates that the Arctic holds $22 \%$ of the World's undiscovered oil and gas wealth. Peter Stauffer, 'us Geological Survey (USGS) Circum-Arctic Resource Appraisal: Estimates of Undiscovered Oil and Gas North of the Arctic Circle' <http://library.arcticportal .org/1554/> accessed 5 October 2015 .

2 Strategic Assessment of Development of the Arctic, 'Developing Oil and Gas Resources in Arctic Waters: The Final Frontier? (factsheet)' (2014) <http://www.arcticinfo.eu/images/ Facksheet/Factsheets_Final/oil_and_gas_factsheet.pdf > accessed 10 August 2016.

3 The Arctic States include the Arctic coastal States, (Russia, Norway, Greenland (and therefore Denmark), the United States and Canada), Iceland (whose EEz extends into the Arctic Ocean), as well as the non-coastal Arctic States of Iceland, Sweden, and Finland.

4 In particular a number of major Asian States, including China, Japan and South Korea) have exhibited a huge interest in arctic (and Antarctic) resources. In addition, China has become an observer to the Arctic Council. For Asian nation's interest in the Arctic see Sanna Kopra, 'China's Arctic Interests' (2013) Arctic Yearbook 107-124; Fujio Ohnishi, 'Does the sun also rise in the Arctic? Three pillars of Japan's Arctic Economy (2015) Arctic Yearbook, 410-412. 
abundant Arctic petroleum resources (oil and gas) has been on the agenda of Arctic States, ${ }^{5}$ giving rise to a perception of intense competition for petroleum resources of the Arctic.

To date there has already been some development of the mineral and petroleum resources. Regarding petroleum development, which is the focus of this chapter, the Snøhvit gas field and Goliat oil field in the Norwegian sector of the Barents Sea are operational. In the Russian Arctic the Yamal gas field, where its LNG terminal is under development, while the Prirazlomnoye oil field in the Pechora Sea is operational. There are also vast known, but as yet undeveloped petroleum resources in the western Russian Arctic, led by the mega Shtokman gas field in the Kara Sea. Russia sees its economic future tied to the Arctic, In an interview in September 2016, First Deputy foreign Minister Vladimir Titov noted that the Arctic zone of the Russian Federation accounts for over $15 \%$ of Russia's GDP, and $20 \%$ of its exports, with this expected to rise. ${ }^{6}$

As part of this rush to harness the Arctic petroleum resources, there is a perception that there has been an overt drive by the Russian Federation to remilitarize their Arctic areas in order to drive the resource exploitation in the Arctic. ${ }^{7}$ Such militarization has been met with varied reception in the media, with headlines ranging from "Russia is Wrapping the Arctic in a Loving,

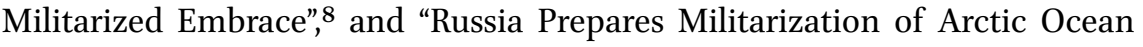
after Huge Oil and Natural Gas Strike", 9 to the fearful headline of Defensetech which proclaims "Russia's Arctic Militarization 'Disturbing', us lawmakers

5 For example, on 21 September 2016 Greenland released a second round of licenses, located onshore at Disko and Nuussuaq, See Greenland opens second onshore licensing round (2016) Arctic Journal, October 4, 2016, <http://arcticjournal.com/oil-minerals/2583/greenland -opens-second-onshore-licensing-round $>$ accessed 29 November 2016.

6 First Deputy foreign Minister Vladimir titov's interview with the ITAR-TAss news agency, September 19, 2016 http://www.mid.ru/en/foreign_policy/news/-/asset_publisher/cKNonk JE02Bw/content/id/2450934.

7 A. Scherbinin, E. Danilova, A. Sentsov, L. Bolsunovskaya and Y. Bolsunovskaya, The Russian Arctic: innovative possibilities at the turn of the past and the future (2015) 27 IOP Science Conference Series: Earth and Environmental Science.

8 John Dyer, 'Russia Is Wrapping the Arctic in a Loving, Militarized Embrace' (Vice News, 22 October 2015) <https://news.vice.com/article/russia-is-wrapping-the-arctic-in-a-loving -militarized-embrace > accessed 16 August 2016.

9 Geoffrey Grider, 'Russia Prepares militarization of Arctic Ocean after huge oil and natural gas strike' (2014) Now The End Begins <http://www.nowtheendbegins.com/russia-prepares -militarization-arctic-ocean-huge-oil-natural-gas-strike/> accessed 29 February 2016. 
say". ${ }^{10}$ These headlines, just a minute sample of the multitude of headlines that have occurred in the last few years, demonstrate the wildly varied responses to Russian sovereign military actions the Russian Arctic territory. These headlines have a partial ring of truth, insofar as they describe the return of a large military presence along the breadth of the Russian Arctic. However, given that the focus of this chapter is on the EU and its relationship with Russia in the Arctic region, a consideration of Russian militarisation and the impacts of such militarisation will be confined to the European Arctic, defined in the EU Strategic Assessment of Development in the Arctic as 'a region extending from Greenland to northwest Russia' and incorporating the Greenland Sea, the Norwegian Sea and the Barents Sea. ${ }^{11}$

Military activities in the Russian Arctic have been largely confined to the establishment or reinvigoration of the Arctic naval bases and power, ${ }^{12}$ as outlined in the 2015 Russian Marine Doctrine. ${ }^{13}$ In this Doctrine, ${ }^{14}$ Russia seeks to regain its status as a blue water force ${ }^{15}$ through a large-scale development of its Navy. The declaration of such expansion and reinvigoration of the Russian navy has been analysed by think tanks in Russia and the us, with the us think tank Centre for Strategic and International Studies concluding that such actions mean that the Russia is undertaking a period of aggression and conflict in the Arctic region. Further, the csis concludes that Russian military buildup and exercises in the region "are obviously not just about economics or safety but indicate a potentially dangerous attempt to return to cold War parity in the

10 Kris Osborn, 'Russia's Arctic Militarization “Disturbing,” us Lawmakers Say' (Defenstech, 12 March 2015) <http://www.defensetech.org/2015/03/12/russias-arctic-militarization -disturbing-us-lawmakers-say/> accessed 16 August 2016.

11 Adam Stepien, Timo Koivurova and Paula Kankaanpää, 'Strategic Assessment of Development of the Arctic: Assessment Conducted for the EU' (2014) $3<$ http://www.arctic info.eu/images/pdf/SADA_report.pdf $>$ accessed 10 August 2016.

12 Lassi Heininen, Alexander Sergunin and Gleb Yarovoy, 'Russian Strategies in the Arctic: Avoiding a New Cold War' (Valdai Club 2015) 36-40 <http://www.uarctic.org/ media/857300/arctic_eng.pdf> accessed 1o August 2016.

13 Russian Federation Marine Doctrine (2015) 26 July 2015. Meeting to discuss the new Russian Marine Strategy on board the frigate Admiral Gorshkov <http://en.kremlin.ru/ events/president/news/50060> accessed 12 December 2015; Russia Marine Doctrine to $2020<$ http://static.kremlin.ru/media/events/files/ru/uAFi5nvux2twaqjftS5yrIZUVTJan77L .pdf $>$ accessed 29 November 2016.

14 Amendments incorporated into the Maritime Doctrine of Russian Federation 2020 $<$ http://www.oceanlaw.org/downloads/arctic/Russian_Maritime_Policy_2020.pdf > accessed 16 August 2016.

15 Blue water force denotes a country with the naval capability to engage in deep-water military operations. 
Arctic."16 Other assessments of Russian military activity is perceived in a neutral manner, with military presence logical given the large concentration of nuclear facilities in the region and the direct access it provides to both the Atlantic and Pacific Oceans. ${ }^{17}$ Russian Arctic strategy is perceived as less ambitious and aggressive, and more cooperative and realistic. ${ }^{18}$ Further, the Valdai Club sees that historical cooperative relationships between Russia and Norway (including the signing of the Barents Sea Agreement in 2010 and the agreement between Rosneft and Statoil for the joint development in the Barents Sea) are a good foundation for a strategic partnership between the two countries, based on cooperation rather than conflict. ${ }^{19}$

Whilst few authors reject the notion that Russia's geo-economic and geostrategic ambitions in the Arctic are considerable, particularly in relation to petroleum resource development, there are two vastly opposing views of Russian military activity in the region. Is Russia an aggressive villain seeking to exploit its Arctic resources in an aggressive manner, or is it maintaining a collaborative and cooperative approach that has been previously demonstrated, particularly in negotiations and agreements relating to Norway and the Barents Sea?

Whichever strategy Russia is undertaking in its resource development, the European Union (EU), as a neighbour and consumer of Arctic resources, has a vested interest in the Russian Arctic Region. This interest is demonstrated by the development of an EU policy towards the European Arctic. ${ }^{20}$ This raises the question which is the subject of this chapter: does EU Arctic policy and the Russian Arctic marine policy seek to implement the same broad objectives in relation to natural resources, and are these policies likely to encourage continued cooperation, or, as the us media would have you believe, ${ }^{21}$ the 2015 Russian

16 Heather A Conley and Caroline Rohloff, ‘The New Ice Curtain: Russia's Strategic Research to the Arctic' (Centre for Strategic and International Studies 2015) 19.

17 Heininen, Sergunin and Yarovoy, n. 12 above, 15-6.

18 Ibid., 88.

19 Ibid., 36-40.

20 This refers to the area of the policy relating to resources and development of the European Arctic as a whole.

21 Especially in the us media. See for example John Dyer, 'Russia is wrapping the Arctic in a loving, militarized embrace (2015) Vice News October 22, $2015<$ https://news .vice.com/article/russia-is-wrapping-the-arctic-in-a-loving-militarized-embrace > accessed 29 February 2016; Geoffrey Grider, 'Russia Prepares militarization of Arctic Ocean after huge oil and natural gas strike' (2014) Now The End Begins < http://www.nowtheendbegins .com/russia-prepares-militarization-arctic-ocean-huge-oil-natural-gas-strike/> accessed 29 February 2016; Kris Osborn, 'Russia's Arctic Militarization 'Disturbing', us lawmakers 
Arctic Marine Policy setting Russia on a course of conflict with other Arctic States? This chapter undertakes a comparative analysis of the EU and Russian policies in relation to petroleum resources in the Arctic. The purpose of this comparative analysis is to determine whether the policies have diverging interests, thereby possibly driving Russia and the EU to conflict over the use and development of the Arctic, or whether the EU and Russia have common Arctic interests that may lead to cooperation in the Arctic region.

In order to undertake this comparative analysis, this chapter first considers EU Arctic policy in relation to resource development in the Arctic, focusing on petroleum resource development. It then undertakes an analysis of Russian Arctic strategy, examining general Russian marine policy as well as Arctic specific policy. Finally, through an analysis of the two policies and current Russian activity in the Arctic, this chapter will determine whether the policies are broadly similar, seeking to implement the same broad objectives, albeit for different motives: Russia as an Arctic State wishing to secure its natural resources, and the EU to access the natural resource bounty the Arctic has to offer the EU and its Member States.

\subsection{EU Petroleum Interest in the Arctic}

The EU has a special interest in the Arctic for a number of reasons. First, and perhaps foremost, the EU maintains an interest in the Arctic since three Member States (Sweden, Denmark and Finland), and two European Economic Areas (EEA) (Norway and Iceland) states lie within or have interests associated with the Arctic.

As noted in the introduction above, it is estimated that vast petroleum resources exist in the Arctic. ${ }^{22}$ These resources are of particular interest for the $\mathrm{EU},{ }^{23}$ given their proximity to European markets. Indeed, the $\mathrm{EU}$ is currently a major destination for goods and resources from the Arctic, with $24 \%$ of Arctic oil and gas output going to the Eu countries. The development of Arctic oil and gas presents a number of challenges and opportunities for the EU economy. ${ }^{24}$ Such opportunities include investment opportunities in the Arctic, coupled

say' (2015) Defensetech 12 March 2015 <http://www.defensetech.org/2015/03/12/russias -arctic-militarization-disturbing-us-lawmakers-say/> accessed 29 February 2016.

22 Stauffer, $n .1$ above.

23 Strategic Assessment of Development of the Arctic, n. 2 above, 9.

24 Strategic Assessment of Development of the Arctic, n. 2 above. 
with the opportunity to undertake research and development in the technological and scientific sectors. ${ }^{25}$

\subsection{EU Arctic Policy}

Given that the Arctic region already plays an important role in the EU, and is likely to become increasingly important in the future, the $\mathrm{EU}$ has developed a policy towards, and strategic assessment of, the Arctic region. A discussion of both the policy and assessment, whilst addressing the global Arctic region, will be confined to the European Arctic ${ }^{26}$ within the confines of this chapter.

Given the emerging strategic and economic importance of the Arctic, an EU Arctic policy was first developed in $2008,{ }^{27}$ calling for a united EU policy on the Arctic. ${ }^{28}$ The EU Arctic policy is built around three main policy objectives:

1) the promotion of the sustainable use of the resources;

2) the protection and preservation of the Arctic in unison with its population; and

3) international cooperation.

\subsubsection{Promotion of Sustainable Use of Resources}

In the European Parliament Resolution of 12 March 2014 on the EU Strategy for the Arctic, the EU acknowledged 'the wish of the inhabitants and governments of the Arctic region with sovereign rights and responsibilities to pursue sustainable economic development....29 Hence, the Eu understands the reality of attempting to balance the inalienable sovereign right of a State to develop its resources with environmental protection. The recognition of a State's sovereignty lies at the heart of the EU, and developing EU Arctic policy respects the right of any state to develop its resources.

\footnotetext{
$25 \quad$ Ibid., 9.

26 As defined in the EU Strategic Assessment of Development in the Arctic as 'a region extending from Greenland to northwest Russia' and incorporating the Greenland Sea, the Norwegian Sea and the Barents Sea. See n. 10 above.

27 European Commission Communication of 20 November 2008 on the European Union and the Arctic Region, сом (2008) 763 .

28 European Parliament Resolution of 12 March 2014 on the EU Strategy for the Arctic (2013/2595RSP), para. 2.

29 European Parliament Resolution of 12 March 2014 on the EU Strategy for the Arctic (2013/2595RSP), para. 42.
} 
Russia is home to the majority of the Arctic petroleum resources, holding 43 of the 61 large hydrocarbon fields. ${ }^{30}$ These substantial resources clearly demonstrate Russian primacy over the area, with these large deposits critical for the EU in the future. Norway holds one large Arctic oil field to date, that of Goliat. In addition, the European Arctic is rich in gas resources, including the giant Shtokman field in Russia, and the Snøhvit field on the Norwegian side of the Barents Sea.

The EU strategic assessment of development of the Arctic by Stepien, Koivurova and Kankaapää identified four main areas that need to be considered in the development of Arctic petroleum resources. ${ }^{31}$ These considerations are environmental, social, economic, and political/governance issues, all of which are closely interlinked and cannot be considered in isolation from each other. ${ }^{32}$ The assessment also recognizes and reiterates that any development of these resources will have impacts and consequences that will be unevenly distributed in the Arctic. ${ }^{33}$ However, the Eu being a major energy market (importing more than EUR40o billion in oil and gas in 2012) ${ }^{34}$ means that EU policy development is firmly focused on how the oil and gas resources of the Arctic region can be developed in a sustainable manner that minimises impact. ${ }^{35}$ As a frontrunner of global climate change mitigation efforts, the EU also emphasizes the necessity of implementation of innovative solutions for the development of renewable energy in the Arctic. ${ }^{36}$

The Council of the EU notes the need for long-term resource policy developments in the Arctic States, including the Barents region, and seeks to pursue long-term partnerships and policy dialogues in order to secure access to raw materials and renewable natural resources. ${ }^{37}$ To that end, EU policy

$30 \quad$ Philip Budzik, 'Arctic Oil and Natural Gas Potential' (us Energy Information Administration 2009) 4.

31 Stepien, Koivurova and Kankaanpää, n. 10 above, 78.

32 Ibid., 78-9.

33 Ibid.

$34 \quad$ Ibid., 81.

35 It is important to note that although the EU Arctic policy is focused on oil and gas resources in the Arctic, the EU has also developed policy towards use of more renewable energy and less dependence on oil and gas, cf. reduction of $\mathrm{CO} 2$ emissions in order to meet its energy needs. However, this chapter will retain a focus on Arctic oil and gas resources as part of the energy security mix.

36 European Parliament Resolution of 12 March 2014 on the EU Strategy for the Arctic (2013/2595RSP), A37, A46.

37 Council of the European Union, 'Council Conclusions on Developing a European Union Policy Towards the Arctic Region' (12 May 2014), para. 11. 
development is focused on innovative research and education in technology and the Arctic environment, and enhanced funding/investment frameworks for environmentally and socially responsible Arctic petroleum projects. ${ }^{38}$

The latest EU Arctic Policy development occurred in April 2016. ${ }^{39}$ In this $2016 \mathrm{EU}$ policy, the need for the sustainable development of the Arctic, including its valuable natural resources, was further enunciated, noting that the European Arctic has significant potential to support growth in the rest of Europe, although it will present some challenges. ${ }^{40}$ In the press release of the 2016 EU Policy, Federica Mogherini, the High Representative of the Union for Foreign Affairs and Security Policy/Vice President of the European Commission noted that

a safe, sustainable and prosperous Arctic not only serves the 4 million people living there, our European Union and the rest of the world. It is a region of immense environmental, social, and economic importance to us all ... the Arctic is also crucial in terms of regional and global security and a strategic component of our foreign policy. ${ }^{41}$

The EU also recognises that sustainable economic development of the natural resources of the Arctic creates specific challenges, primarily due to sparse populations and a lack of transport infrastructure. ${ }^{42}$ Such challenges are enhanced by an incomplete north-south traffic connection, and the need to strengthening Arctic transport links through trans-European networks. It is recognised that the strengthening of transport links for sustainable development of Arctic natural resources will also require cooperation between EU and EEA member-states. ${ }^{43}$

It is likely that the Arctic will be one of the areas of the earth most affected by climate change, ${ }^{44}$ most dramatically demonstrated by the projection that the Arctic Ocean will become largely ice-free in summer within the next thirty

\footnotetext{
38 Stepien, Koivurova and Kankaanpää n. 10 above, 85 .

39 European Commission and The High Representative, 'An integrated European Union policy for the Arctic', Joint Communication, JOIN (2016) 21 final.

$40 \quad$ Ibid, 8-9.

41 European Commission, 'A New Integrated Eu Policy for the Arctic Adopted [press release]' <http://europa.eu/rapid/press-release_IP-16-1539_en.htm> accessed 16 August 2016.

$42 \operatorname{JOIN}(2016) 21,8$.

43 Ibid.

44 Ibid., 5 .
} 
years. ${ }^{45} \mathrm{~A}$ dramatic change in the quantity and quality of ice has already established a commercial shipping route through the Arctic, known as the Northern Sea Route (NSR). ${ }^{46}$ An analysis of the NSR transits identifies that although transit numbers are low, there has been a $1000 \%$ increase in the number of transits since 2009, ${ }^{47}$ signaling the future use of the area and the need for the development of a policy and strategy prior to the mainstream use of the NSR as a sea route. ${ }^{48}$

In view of such increasing shipping in the Arctic, including vessels carrying flags from EU Member States, the 2016 EU Policy recognizes that the EU should contribute to increased safety of navigation in the Arctic, particularly through innovative technologies, and the development of spatial and temporal monitoring tools to increase knowledge for the assessment of risks and the mitigation of identified risks. ${ }^{49}$

The governance of the NSR and the use of oceans within the Arctic are within the remit of the United Nations Convention on the Law of The Sea (UNCLOS)..$^{50}$ Article 234 of the UnClos, or so-called 'Arctic clause', allows States whose Exclusive Economic Zone (EEZ) is ice-covered to 'to adopt and enforce nondiscriminatory laws and regulations for the prevention, reduction and control of marine pollution from vessels. ${ }^{51}$ Russia has made use of this clause by developing 'most comprehensive' regulations for the prevention, reduction and control of marine pollution. ${ }^{22}$ As the NSR lies mostly in the Russian internal waters and $\mathrm{EEZ}$, it is these regulations that control the shipping on the route. ${ }^{53}$

\subsubsection{International Cooperation}

Given the EU reliance on and interest in the resources of the Arctic, EU policy recognizes the strategic importance of the Arctic, and identifies it as an area of successful international cooperation contributing to peace and security in

\footnotetext{
$45 \quad$ Ibid., 2.

46 By the end of the 2014-15 season, transits across the northern sea route included bother internal transits (wholly within Russian Federation) as well as transits from the Barents Sea to the Bering Strait.

47 Transit numbers rose from 4 in 2009 to 40 in 2013 season.

48 Stepien, Koivurova and Kankaanpää, n. 10 above, 39.

49 JOIN (2016) 21,12.

50 United Nations Convention on Law of the Sea (signed 10 December 1982, entered into force 16 November 1994) 1833 UNTS 3 (UNCLOS).

51 Article 234, UNCLOS.

52 Stepien, Koivurova and Kankaanpää, n. 10 above, 46.

53 Brubaker R Douglas, 'Straits in the Russian Arctic' (2001) 32 (3) Ocean Development and International Law 263.
} 
the region. ${ }^{54}$ Thus, there has been an ongoing development and commitment to an EU Arctic policy.

The EU seeks to engage more with Arctic partners in order to address common challenges in a collaborative manner. ${ }^{55}$ It also sees the conclusion of the maritime delimitation between Russia and Norway, and ongoing cooperation in the Barents Sea, as positive examples of cooperation. ${ }^{56}$ It regards the Barents Euro-Arctic Cooperation (BEAC) as an important hub for cooperation between EU countries (Denmark, Finland and Sweden), as well as Norway, Russia and the European Commission. ${ }^{57}$

In developing its Arctic policy, the EU has taken note of recent exploration activities in European Arctic and Barents Sea, and especially the bilateral cooperation between Norway and Russia, particularly in relation to environmental protection in the prospecting for oil and gas in the region. ${ }^{58}$

As part of the developing Arctic policy, the Council of the EU has identified the need for the EU to enhance its contribution to Arctic cooperation by conforming to international instruments, especially UNCLOS. ${ }^{59}$ It also reiterates the importance of respecting international law principles with regard to transArctic ocean routes, including the NSR. ${ }^{60}$ Alongside this engagement, the EU seeks to increase dialogue with Arctic States. ${ }^{61}$ To date, such engagement has occurred through the development of EU policy, engagement with the BEAC, and seeking admission to Arctic Council (which to date has not yet come to fruition).

The 2016 EU Arctic Policy recognizes that the Arctic region has acquired a higher profile in international relations due to the increasing environmental, social, economic and strategic importance of the Arctic. ${ }^{62}$ Furthermore, the 2016 EU Policy notes that changes affecting the Arctic, although presenting opportunities, also have the potential to increase tensions in the area,

54 JOIN (2016) 21, 3; European Commission and The High Representative Joint Communication 'Developing a European Union Policy towards the Arctic Region: Progress since 2008 and next Steps' JOIN(2012) 19 final.

55 JOIN (2012) 19, 3 .

$56 \quad$ Ibid.

57 European Parliament Resolution on the EU Strategy for the Arctic (12 March 2014) 2013/2595RSP, para. 7 .

$5^{8} \quad$ Ibid, para. 54 .

59 Council Conclusions on Developing a European Union Policy Towards the Arctic Region' (12 May 2014), para. 3.

6 Ibid, para. 10.

61 JOIN (2012) 19, 4.

$62 \operatorname{JOIN}(2016) 21,3$. 
rendering constructive international cooperation more important than ever. ${ }^{63}$ The $2016 \mathrm{EU}$ Arctic policy recognizes that there is a need for a network for the Arctic and Atlantic to address maritime security threats associated with the opening of the $\mathrm{NSR}^{64}$ as well as supporting the soon to be introduced IMO Polar Code.

\subsubsection{A Developing EU Arctic Policy}

An analysis of EU Arctic policy demonstrates that the foundation of EU Arctic policy - the sustainable development of natural resources-remains important in the region and sits alongside the development, utilization and safety of the marine shipping capacity of the region. The EU seeks to undertake such development and utilization within a framework of international cooperation. Such cooperation between the EU and/EU actors and Russia in the Arctic is long standing, spanning the previous twenty years. As the EU seeks to clarify and develop its policy toward the Arctic, the question remains whether the Russian Arctic policy remains cooperative, or whether it is entering a more 'bullish' phase with a shifting focus to one of a more aggressive nature, with the cooperative nature of previous relationships in the Arctic shifting with it.

\section{Russian Arctic Policy-A New Strategy or More of the Same?}

Russian Arctic policy is inextricably tied up with Russian marine policy, given that the region includes a huge expanse of ocean. In the 21st century Russia has identified the Arctic as playing a vital dual role: strategic priority and a resource base for future development. ${ }^{65}$

\subsection{Post Soviet Interest in the Arctic-The Development of Maritime Policy}

Almost immediately after coming to power, Russian president Vladimir Putin set forth on a path of rebuilding Russia, particularly through the development of Russian industry. A key strategy in this redevelopment of the Russian Federation was the 2001 Maritime Doctrine of the Russian Federation 2020

\footnotetext{
63 Ibid., 4.

64 Ibid., 13.

65 Ekaterina Klimenko, 'Russia's Evolving Arctic Strategy: Drivers, Challenges and New Opportunities' (Stockholm International Peace Research Institute 2014) Policy Paper 42, 1.
} 
(the 2001 Doctrine).66 The legal basis of 2001 Doctrine is the Constitution of the Russian Federation, the federal laws of the Russian Federation, UnClos, international maritime treaties and the use of the ocean. ${ }^{67}$ The 2001 Doctrine sets out Russia's national maritime interests, and continues to remain the fundamental Doctrine for the Russian Maritime area. The 2001 Doctrine sets out the inviolability of the sovereignty of the Russian Federation in its internal waters, as well as its sovereign rights over the E EZ and continental shelf. ${ }^{68}$ It recognises the sovereign rights and jurisdiction of the Russian Federation in the exploitation, development and conservation of living and non-living marine natural resources. ${ }^{69}$ This declaration of interests in the maritime zones under the 2001 Doctrine is similar to the declaration of the UK over its continental shelf in section 1 of the Continental Shelf Act 1964 and the Norwegian government declaration over natural resources on the Norwegian Continental Shelf in $1963 .{ }^{70}$ Other Russian interests specifically articulated in the 2001 Doctrine include freedom of high seas, protection of human life at sea, the prevention of marine pollution the control of marine communications and the creation of conditions conducive to benefit marine economic activity. ${ }^{71}$

In articulating Russian marine interests, the 2001 Doctrine sets out a number of objectives of national marine policy (NMP) related to the development of petroleum resources. These include:

- The preservation of sovereignty of inland waters, the Territorial Sea and the airspace and subsoil of these areas;

66 Article 1: General Provisions, Vladimir Putin, 'Maritime Doctrine of Russian Federation 2020' (2001) $1<$ http://www.oceanlaw.org/downloads/arctic/Russian_Maritime_Policy_2020 .pdf $>$ accessed 16 August 2016.

67 Ibid.

68 In accordance with the United Nation Convention of the Law of the Sea (UNCLOS), the Federal Act on the internal maritime waters, territorial sea and contiguous zone of the Russian Federation, 17 July 1998 <http://www.un.org/depts/los/ LEGISLATIONANDTREATIES/PDFFILES/RUS_1998_Act_TS.pdf> accessed 1 December 2016; and the Federal Act on the Exclusive Economic Zone of the Russian Federation, 2 December 1998 <http://www.un.org/depts/los/LEGISLATIONANDTREATIES/PDF FILES/RUS_1998_Act_EZ.pdf > accessed 1 December 2016.

69 Putin, n. 66 above.

70 Act of 21 June 1963 no 12 relating to scientific research and exploration for and exploitation of subsea natural resources other than petroleum resources, as amended 6 June 2008 (Norway), Section $2<$ http://www.npd.no/en/Regulations/Acts/Scientific-research-act> accessed 29 November 2016.

71 Putin, n. 66 above, 2. 
- Protection of sovereign rights on EEZ and Cs for the development of natural resources, including the construction and operation of artificial islands, installations and other structures, and.

- Protection of the Russian Federation with the marine areas, protection of national borders, including sea and air space. ${ }^{72}$

In addition, the 2001 doctrine outlines the principles of the NMP:

- Compliance with generally accepted norms of international law and international treaties of the Russian federation in the implementation of maritime activities;

- The priority of political (diplomatic, economic, information and other non-military means) means in resolving conflict in the oceans and remove threats to national security;

- The possession of naval capabilities, and its effective use to support marine activities;

- Maintaining maritime capabilities consistent with national interests including the presence of a Russian fleet in remote areas of the oceans; and

- Construction and infrastructure development for the Russian fleet within RF maintenance of fleet to meet existing and emerging challenges; and

- The readiness of specialized fleets, including commercial, research, and fishery vessels. ${ }^{73}$

In developing the 2001 Doctrine, Russia outlines its interests in its seas. These interests in the Arctic can be divided into two main areas-shipping and the NSR, and resource development.

\subsection{Shipping and the Northern Sea Route}

Russian interest in the Arctic is not confined to this century, rather going back many centuries, with particular focus since the beginning of the last century. The defeat of Russia at the hands of the Japanese in 1905 illustrated the need for rapid movement of soldiers and goods from the populous west to the east where an increasingly militarized Japan posed a serious threat to the Russian empire. After this defeat, money was made available for the development of the NSR, to enable faster mobilization of troops and resources to the area. ${ }^{74}$

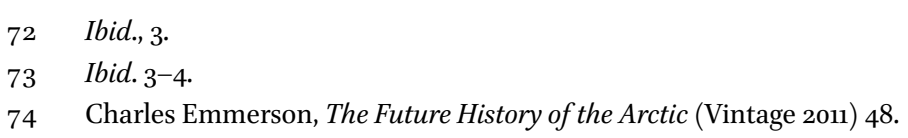


A notable navigation of the NSR occurred in 1932, when a one-year navigation test of the NSR was undertaken by Otto Schmidt. ${ }^{75}$ At this time the Soviet government also set up the administrative body Glavsevmorput, with the aim of developing Soviet Arctic domains, especially the NSR. ${ }^{76}$ Engagement with the NSR and the Soviet Arctic region continued with the deployment of a drifting Arctic research station in the $1937-8$ winter. ${ }^{77}$ The Russian Arctic zone continued to be developed both on land and sea, with the rapid development of the city of Murmansk from 1938 as a Northern Sea Port (given its largely ice-free status and location), as well as the Kola Peninsula (including Murmansk) and Archangelsk for resource development. During the Soviet era the role of the NSR was the transport of cargo, people and raw materials east and west along the Arctic route rather than as a transit route for cargo from the Atlantic to the Pacific. ${ }^{78}$ However, the breakup of the Soviet Union saw the decline of the USSR military might, with the Murmansk Northern Sea Base in particular entering a stage of rapid decay. Such decay was highlighted in August 2000 with the Kursk tragedy, when the Russian Navy lacked the capability to launch a rescue of the crew of the Kursk. ${ }^{79}$

Ongoing use of domestic maritime transport in Russia is crucial, particularly in the Far North where shipping is the only mode of transport, and is essential for sustenance. To achieve the development of the north and shipping in the region the Russian government set out a long-term objective in the 2001 Doctrine for the formation of a regulatory framework for marine activities in compliance with international law, taking into account Russian national interests. ${ }^{80}$ The importance of development of national interests of the Russian Federation in the Arctic was reiterated under Part II of the Basics of the State Policy of the Russian Federation in the Arctic for the Period till 2020 and for a Further Perspective (2008 Russian Arctic Policy). ${ }^{81}$ In particular, Article 7 (d) of the 2008 Arctic Russian Policy prioritizes, as a matter of

$75 \quad$ Ibid., 64 .

76 Ibid., 53 .

77 Ibid., 64.

78 Claes L. Ragner, 'Den Norra Sjövägen' in Torsten Hallberg (ed), Barents—ett Gräsland I Norden (Arena Norden 2008) 116, English translation at <http://www.fni.no/pdf/clrnorden-nsr-en.PDF> accessed 16 August 2016.

79 Zoltan Barany, Democratic Breaksown and the decline of the Russian Military (Princeton University Press, 2009) 19-43.

$80 \quad$ Putin, n. 66 above, 3 .

81 Dimitry Medvedev, 'Basics of the State Policy of the Russian Federation in the Arctic for the Period till 2020 and for a Further Perspective' (2008) <http://www.arctis-search.com/ Russian+Federation+Policy+for+the+Arctic+to+2020> accessed 16 August 2016. 
strategic interest for the Russian Federation in the Arctic, assistance in the organization and effective utilization of the NSR for international navigation under Russian jurisdiction, in accordance with international treaties. Article 8 (b) of the 2008 Arctic Russian Policy identifies that such development of the NSR will necessarily require the security, defense and protection of the Russian border along the NSR.

The recently announced draft 2015 Russian Marine Doctrine (the 2015 Doctrine) set out additional strategies to promote the development of shipping, particularly in the Arctic. At the launch of the Doctrine, Deputy Prime Minister Rogozin outlined a plan for the resurgence of shipbuilding, with an emphasis on icebreakers. ${ }^{82}$ The 2015 Doctrine attributes the resurgence of shipbuilding and icebreakers, the largest development in the post-Soviet era, to the growing importance of the Northern Sea Route. ${ }^{83}$ To meet the growing importance, Rogozin identified the development of three new atomic icebreakers, which would be ready to accompany ships in the NSR in 2017, 2019, and 2020 respectively. ${ }^{84}$ Such commitment to the NSR was further strengthened in 2016 with the release of the Foreign Policy Concept of the Russian Federation. ${ }^{85}$ Under this Concept, Russia clearly reiterates the importance of the NSR, stating that the use of the NSR as Russia's national transport route in the arctic, as well as for transit shipments between Europe and Asia is significant for the development of the region. ${ }^{86}$

\subsection{Development and Conservation of Natural Resources}

The value of natural resources in the High North has long been identified. As Nansen travelled down the Yenisei River in 1913, he expressed the possibility that Siberia would become a European resource base for the future. ${ }^{87}$

82 'Russian Maritime Doctrine' President of Russia Website (26 July 2015) <http://en.kremlin .ru/events/president/news/5006o> accessed 16 August 2016.

83 Ibid.

84 Ibid.

85 Foreign Policy Concept of the Russian Federation (approved by President of the Russian Federation Vladimir Putin on November 30 2016) <http://www.mid.ru/en/foreign policy/official_documents/-/asset_publisher/CptICkB6BZ29/content/id/2542248> accessed 4 Feburary 2017.

86 Foreign Policy Concept of the Russian Federation (approved by President of the Russian Federation Vladimir Putin on November 30 2016) Arcticle 76 <http://www.mid.ru/en/ foreign_policy/official_documents/-/asset_publisher/CptICkB6BZ29/content/id/2542248> accessed 4 Feburary 2017.

87 Emmerson, n. 74 above, 40. 
Since the early 2oth century Russia has been a natural resources leader in the Arctic - in the early 1930s the value of Arctic minerals for Soviet Russia was identified by Stalin, who stated ...' the Arctic and our northern regions contain colossal wealth. We must create a soviet organisation, which can, in the shortest period possible, include this wealth in the general resources of our socialist economic structure. 88

This expansionist policy of Russia in relation to Arctic mineral wealth is also demonstrated by the acquisition of the Barentsburg coal mining operation on Svalbard from Sweden in 1927, with operation continuing until 1998, beyond the end of the soviet era. ${ }^{89}$ However, although there is an abundance of resources in the Russian north, there is also an acceptance that the economic exploitation of the Russian High North needs to overcome some major obstacles-the cold, the dark and the ice. ${ }^{90}$ Russia was able to largely overcome these obstacles to the development of resources in the region through a massive expansion in the capitals on high north, assisted greatly by the Gulag system, which provided labour to develop necessary infrastructure..$^{91}$ The other great tool in the development of Arctic mineral wealth was the pioneering development of icebreakers. Russia developed the first atomic icebreakers, including the Lenin in 1959, followed by the Arctic class atomic icebreakers with the Arktika in 1975, Sibit (1977), Rossiya 1985, and Sovietskiy Soyuz in 1989.

The development of ocean resources, and in particular the development of mineral and petroleum resources was highlighted in the 2001 Doctrine, outlining the need for advanced geological studies of the Russian Arctic, ${ }^{92}$ and the need for state control in the development of these resources..$^{93}$ The 2001 Doctrine recognizes international law, and the requirement to adhere to international law, especially UNCLOS and the International Seabed Authority, in the development of these resources. The 2001 Doctrine sees the implementation of increased naval activity as critical to the exploitation of these Arctic resources and the navy as essential for the protection and promotion of national interests and the security of the Russian Federation in the oceans.

\footnotetext{
$88 \quad$ Ibid., 35 .

89 Rachel Nuwer, 'A Soviet Ghost Town in the Arctic Circle, Pyramiden Stands Alone' (Smithsonian, 19 May 2014) <http://www.smithsonianmag.com/travel/soviet-ghost-town -arctic-circle-pyramiden-stands-alone-180951429/?no-ist> accessed 19 August 2016.

90 Emmerson, n. 74 above, $5^{0 .}$

91 For example the Gulag system at the Solovetsky Islands and Monastery. See Anne Applebaum, Gulag: A history (Doubleday, 1994).

92 Putin, n. 66 above, 7.

93 Ibid., 9 .
} 
In line with the 2001 Doctrine, Russia has increased military exercises in the region, as well as reinstating the Northern fleet and undertaken regional deployment of military forces. Such militarisation has not gone unnoticed by the Norwegian Intelligence Service (NIS), which notes that

Russia has taken a number of steps to flag and secure its interests in the Arctic. On 1 December 2014, the country formally established a joint military Arctic command, and the Russians have also reopened old bases and established a permanent presence in new locations across the Arctic. An infantry brigade has been re-established on the border with Finland. ${ }^{94}$

The 2013 Russian Strategy of the Development of the Arctic (2013 Arctic Strategy) ${ }^{95}$ further enforces this development of the Arctic resources. Article 11 of the 2013 Arctic Strategy outlines the use and development of the Arctic resources. In particular, the strategy outlines the implementation of large infrastructure projects in Russia's Arctic zone, particularly the hydrocarbon deposits on the continental shelf of the Barents, Pechora and Kara Seas, and the Yamal and Gydan Peninsulas. ${ }^{96}$

The importance of Arctic natural resources was also identified in the 2015 Russina Maritime Doctrine. Aside from the importance of the NSR, Deputy Prime Minister Rogozin emphasized that 'there are the riches of continental shelf, the development of which calls for an attentive approach, ${ }^{97}$ thereby reinforcing the need for the development of atomic icebreakers and the development of the north.

\subsection{Longstanding Northern Policy}

There is a clear and longstanding Russian strategy for the development of European Arctic, especially in relation to shipping (the Arctic as both a destination and a transit route) and natural resource development. Such a policy was commenced in former soviet times, and after the collapse of the Soviet Union was resurrected and articulated in the 2001 Doctrine, clarified in the

94 Norwegian Intelligence Service, 'Focus' (2015) Annual assessment $20<\mathrm{https}$ ://forsvaret .no/fakta_/ForsvaretDocuments/Focus2015-ENG_hele_lav_19.05.pdf > accessed 16 August 2016.

95 Russian Strategy of the Development of the Arctic Zone and the Provision of National Security until 2020 (adopted by the President of the Russian Federation on February 8 2013, No. Pr-232.

96 Russian Strategy of the Development of the Arctic Zone and the Provision of National Security until 2020 (adopted by the President of the Russian Federation on February 8 2013, $\mathrm{N}^{\circ}$. Pr-232, Article 11(d) and (e).

'Russian Maritime Doctrine', n. 82 above. 
2008 Russian Arctic Policy, and reinforced in the 2013 Arctic Strategy and the 2015 Doctrine. Such strategies create two fundamental questions. Firstly, is the Russian policy position regarding the Arctic fundamentally different to the policy position of the EU? Secondly, does current Russian Arctic strategy and policy demonstrate a cooperative approach to Arctic development? ${ }^{98}$

\section{4 Russia—EU Interests in the Arctic—Convergence or Divergence?}

\subsection{Is Russian Arctic Policy Fundamentally Different to EU Arctic Policy?}

The Russian Arctic policy is clearly articulated in the 2001 Doctrine, which outlines a focus on two main areas in the Arctic: the development of the NSR for both internal and transit shipping, and the exploitation of natural resources in the Russian Arctic, especially the petroleum. The development of these two main areas is seen as long-term strategies, essential for the future of the Russian Federation. This policy approach has been implemented since the beginning of the 21st century, and reiterated in the recent 2015 Doctrine. There is recognition that the development of resources in the Russian Arctic will require infrastructure, and that the European High North lacks sufficient infrastructure at present. Commitment to environmental protection in the Arctic is also recognized by Russia's participation in the petroleum standards developed as part of the Barents 2020 project, providing a great advance in environmental protection for the Arctic. ${ }^{99}$

An analysis of EU Arctic policy in Section 2 reveals that the EU focused on two similar issues to that of Russia. The first issue is that of resource development in the Arctic, arising since the EU is a major petroleum consumer, importing more than EUR40o billion in oil and gas in 2012. ${ }^{100}$ This need for access to petroleum resources by the EU, and Russian desire to develop its petroleum resources indicates a symbiotic policy relationship between the EU and Russia, reminiscent of the 199os when the Energy Charter Treaty 1994 was forged: Russian Arctic policy highlights a commodity it seeks to develop, and the EU policy indicates the EU seeks to acquire Arctic petroleum resources. Regarding the NSR, a symbiosis between Russian and EU Arctic policy also

\footnotetext{
98 Sean MacCormac, 'The New Russian Naval Doctrine' Center for International Maritime Security (24 November 2015) <http://cimsec.org/new-russian-naval-doctrine/18444> accessed 16 August 2016.

99 European Parliament Resolution on the EU Strategy for the Arctic (12 March 2014) 2013/2595RSP, para. 54.

100 Stepien, Koivurova and Kankaanpää, n. 10 above, 81.
} 
exists. ${ }^{101}$ The EU seeks to protect the Arctic and gain access to shipping routes, and the Russian Federation seeks to develop and control the NSR in order to protect and preserve the Arctic environment for future generations. ${ }^{102}$

\subsection{Does Current Russian Arctic Policy Mark a Shift From Cooperative Arctic Development?}

The EU has clearly and specifically articulated the need for any development of the Arctic to occur through cooperation. In the past, Russia's conduct has been viewed as cooperative in nature, and its Arctic Policy has been overtly cooperative: Article 6(f) of the Basics of the State Policy of the Russian Federation in the Arctic for the Period til 2020 and for a Further Perspective explicitly states that in the sphere of international cooperation, there is a basic objective to maintain a mutually advantageous bilateral and multilateral cooperation between the Russian Federation and the sub-Arctic States on the basis of international treaties and agreements to which the Russian Federation is a party. ${ }^{103}$

However, military activity in the Arctic, especially the remilitarization of the Murmansk naval base, combined with the recent announcement of the 2015 Doctrine, has prompted some authors to question whether this marks a shift in Russian Arctic policy from one of cooperation to one of conflict. Such concern is articulated by Sean McCormac from the Center for Maritime Security (CIMSEC), who notes that 'what is of greatest concern to America's strategic planners is Russia's interest in control of the Arctic and the natural resources in the waters there-Russia's control of the Arctic is a possibility that should not be lightly dismissed.'104 Given the low oil price at present, the motives of Russia in developing Arctic petroleum resources, which are expensive to extract, ${ }^{105}$ are being questioned. Although much of the discussion regarding the development of Arctic resources during 2015 focused on the economic climate and low oil prices, and hence the peril of developing Arctic petroleum

101 This symbiosis is based on a recognition of current Russian maritime boundaries, and does not incorporate the areas subject to a submission to the Law of the Sea Commission regarding the extension of the limits of the Russian continental shelf.

102 As articulated by Deputy Prime Minister Dmitry Medvedev in 'Russian Maritime Doctrine', n. 82 above.

103 Medvedev, n. 81 above.

104 CIMSEC sees this remilitarization as a move to Russian aggression. See MacCormac, n. 95 above.

105 'Opportunities and Challenges for Arctic Oil and Gas Development' (Wilson Center 2014) <https://www.wilsoncenter.org/sites/default/files/Arctic\%2oReport_F2.pdf> accessed 30 November 2016. 
resources, Russian Arctic policy, as demonstrated by the 2001 doctrine and the 2015 Doctrine, is a long-term strategy, designed to fuel a long-term resurgence of economic growth and development. ${ }^{106}$

In order to develop the resources of the region, there is a need for the development of critical infrastructure resources, including the NSR, which is necessary for the transport of resources that are exploited in the region. Russian strategy to date, which has also been demonstrated in the Soviet era, is to develop critical infrastructure in the region. Such critical infrastructure development has been based largely (although not exclusively) on the use of prison labour under the gulag system, ${ }^{107}$ and militarization for the development of infrastructure. ${ }^{108}$

Western media has reported, often with appropriate scaremongering, that Russia plans to reopen military bases it abandoned after the Soviet Union collapsed. ${ }^{109}$ Journalists have raised fear about such a move, citing such militarization comes at a time heightened tensions with the West over Ukraine that 'saw Russia increase its air patrols probing NATo's borders, including in the Arctic.' ${ }^{110}$ The Centre for Strategic International Studies (CSIs) questions whether recent Russian military exercises and the opening of previously closed soviet-era military bases in the arctic are proportional to the use of the NSR or to deploy in search and rescue and oil spill response Agreements that Russia has signed. ${ }^{111}$ In its analysis, CSIS interprets Russian activity as a form of aggression, and 'Russia's military buildup and demonstrations of capability are obviously not just about economics or safety but indicate a potentially dangerous attempt to return to Cold War Parity in the Arctic.'112 Such a view is at odds with Norway, Russia's neighbour, which has concluded that the relationship between Russia and the West is not at its coldest since the Cold War. ${ }^{113}$ Russia itself

106 International Institute for Strategic Studies, 'Russia in the Arctic: Economic interests override military operations' (2012) 19 (9) Strategic Comments vi-viii.

107 See for instance Magadan-Yakutsk road ('the road of a million bones') and Smolensky Islands.

108 See for example the establishment of the port of Murmansk from the first world was period, and in particular the development of Murmansk during and after World War 2.

109 L. van Geuns and S de Jong, 'West Should Respond to Russian Militarization of the Arctic' Atlantic Community (7 September 2015) <http://www.atlantic-community.org/-/west -should-respond-to-russian-militarization-of-the-arctic > accessed 16 August 2016.

110 Ibid.

111 Conley and Rohloff, n. 16 above, IX, 15 .

112 Ibid., 19.

113 Trude Pettersen, 'Norwegian Intelligence Service: Russia Is More Confident and Unpredictable' (The Independent Barents Observer, 24 February 2016) <http://www .thebarentsobserver.com/2016/o2/norwegian-intelligence-service-russia-more-confident 
has also iterated its position regarding militarisation in the Arctic, with first Deputy foreign Minister Titov dispelling any perception of militarization in the arctic:

... Russia does not see any challenges in that area [the Arctic] that would have a military dimension. Russia will continue to oppose any attempts to portray the region as an area of future conflict, and intends, for its part, to promote the idea of the arctic as a territory of peace and cooperation. ${ }^{114}$

It is critical to note that one motive articulated by Russia for increased militarization in the Arctic is its leadership and commitment to the binding (hard law) components of the Arctic Council, Search and Rescue in the Arctic Agreement (SAR), ${ }^{115}$ and Cooperation on Marine Oil Pollution Preparedness and Response in the Arctic (MOPPR). ${ }^{116}$ Russia has argued that the remilitarization of the region is required in order to meet the SAR and MOPPR obligations. Such claims are rejected by western (dominantly the Us) authors, who instead cite aggression and conflict associated with Ukraine as reasons for military action. ${ }^{117}$ Although doubted by some academics, the role of the military in civilian maritime activities is evidenced in several Arctic States, including the us and Norway. The Norwegian Coast Guard is a part of the Norwegian Navy, to ensure that it receives the necessary training personnel and maintenance to undertake operations from their northern base in Sortland. ${ }^{118}$ Similarly, the us Coast Guard (USCG) is one of the five branches of the Us military, and the only military organisation within the Department of Homeland Security. ${ }^{119}$ The role of the USCG is to safeguard Us maritime interests around the world. ${ }^{120}$ This is not

-and-unpredictable> accessed 19 August 2016. Note that the Norwegian intelligence service report for 2016 is only available in Norwegian at present, and therefore there is a reliance on reports in the media regarding the content of the report.

114 First Deputy foreign Minister Vladimir titov's interview with the ITAR-TAss news agency, September 19, 2016 <http://www.mid.ru/en/foreign_policy/news/-/asset_publisher/ cKNonkJE02Bw/content/id/2450934> accessed 4 Feburary 2017.

115 Agreement on Cooperation on Aeronautical and Maritime Search and Rescue in the Arctic (signed 12 May 2011, entered into force 19 January 2013).

116 Agreement on Cooperation on Marine Oil Pollution Preparedness and Response in the Arctic (signed 15 May 2013, entered into force 25 March 2016).

117 See van Geuns and de Jong, n. 113 above; Conley and Rohloff, n. 16 above.

118 Forsvaret (the Norwegian Armed Forces) website, The Navy <https://forsvaret.no/en/ organisation/navy> accessed 16 August 2016.

119 Us Coast Guard, 'Doctrine for the US Coast Guard' (2014) 59 <http://www.uscg.mil/ doctrine/CGPub/Pub_1.pdf> accessed 16 August 2016.

120 Ibid. 
dissimilar to the Russian Coast Guard that has been taken under the auspices of the Federal Secruity services of the Russian Federation (the FSB) in order to secure and protect national interests. Such Russian militarisation of the Arctic can be viewed within the lens of infrastructure development, given that establishment of military bases provides essential infrastructure that can be built on and extended for civilian purposes, such as for petroleum resource development. ${ }^{121}$ In the $2016 \mathrm{EU}$ Policy, the European Commission specifically identified the challenges of sustainably developing Arctic natural resources due to the lack of transport links and infrastructure. ${ }^{122}$ The need for infrastructure in the high North was also identified by the Norwegian government in the Barents 2020 report in 2006, which concluded that Norway has 'well developed infrastructure in northern parts of the country. In Russia, much of this experience is lacking, and supply systems are of an inferior standard compared with those on the Norwegian side of the border.'123 The role of the military in establishing infrastructure in a region that lacks sufficient infrastructure is recognised by the us military, which notes that 'the infrastructure required to support military operations is similar in nature to that which is required by a nation's population as a whole.' ${ }^{124}$ In addition, there is also recognition that often the military is the only organisation with the capacity, skills and materials to establish critical infrastructure in areas where infrastructure is lacking or destroyed. ${ }^{125}$ The lack of threat that the Russian militarisation poses in the Arctic has been the subject of a study by the Norwegian Intelligence Service (NIS). ${ }^{126}$ Whilst the NIS acknowledges that 'Russia has demonstrated increased military capacity, as shown in Ukraine annexation and the Syrian campaign, ${ }^{, 27}$ it has established that Russia presently poses no immediate military threat to Norway, although Russia's increased presence in the North and upgraded military power has increased the

121 The essential use of military in the Arctic region for operations (such as search and rescue) has also been recognized by the us military. See Col. John L. Conway III, 'Search and Rescue in the High North: An Air force Mission?' (2013) 27 (6) Air and Space Power Journal $4^{-24}$.

122 JOIN (2016) 21, 8.

123 Norwegian government, Barents 2020: A Tool for a forward-looking High North Policy (2006), <https://www.regjeringen.no/globalassets/upload/ud/vedlegg/barents2o2oe.pdf> accessed 12 February 2016, p 15.

124 Alan L. Webster, 'The Role of the Army in Infrastructure and Capacity Building' (2010) p. 15 $<$ http://handle.dtic.mil/100.2/ADA522051> accessed 16 August 2016.

125 Ibid., 15 .

126 Norwegian Intelligence Service, 'Focus' (2015) Annual assessment $20<\mathrm{https}$ //forsvaret .no/fakta_/ForsvaretDocuments/Focus2015-ENG_hele_lav_19.05.pdf > accessed 16 August 2016.

Pettersen, n. 113 above. 
ability of Russia to influence Norway's freedom to act in the region. ${ }^{128}$ Indeed, the NIs has concluded that:

despite significant military and security policy shifts in 2014, NIS maintains that Russia does not, in the current situation, pose a military threat to Norway. Threats arise from a combination of capability and intention, and although Russia's capability is increasing it is currently difficult to envision any rational basis for Russian military action against Norway in the short to medium term. ${ }^{129}$

Thus, it would appear that Norway has concluded that Russia poses no military threat to Norwegian sovereignty. Such a conclusion is also supported by the $\mathrm{EU}$, which recognizes that there is a lack of facilities and services in the region, and that the Russian government seeks to upgrade facilities and services in the region. ${ }^{130}$ The EU also recognizes that there are severe shortcomings to Arctic marine infrastructure, particularly hydrographic surveys for extensive knowledge of the bathymetry. ${ }^{131}$ Russia is naturally a State, along with Norway, that is likely to play a role in the region. It is likely that the role Russia plays will be particularly related to maritime affairs, and include port reception facilities for ship waste, a place of refuge in bad weather, oil spill contingency planning equipment depots, provision of hydrographic surveys, and provide refueling stations for the NSR. However, what remains questionable, is how well these critical roles will sit with other international actors.

A commonality that exists between Russian and EU Arctic policy is that of cooperation. Whereas legal instruments dominate international cooperation and use of Antarctica, the Arctic has been dominated by international cooperation, particularly in the form of 'soft law'. The development of soft law in the Arctic, based on cooperation has been led by the Arctic Council, of which Russia has played a leading and cooperative role to date. As well as developing a body of soft law, the Arctic Council has developed a number of legally binding instruments in relation to resource development and increased maritime activity in the Arctic: an agreement on search and rescue in the Arctic (SAR), and cooperation on marine oil spill preparedness and response in the Arctic (MOPPR). In doing so, the Arctic Council has morphed from soft law to hard law, from non-binding to binding instruments. In undertaking this

\footnotetext{
128 Ibid.

129 Norwegian Intelligence Service, n. 94 above.

130 Stepien, Koivurova and Kankaanpää, n. 10 above, 42.

131 Ibid., 39.
} 
transformation to hard law, Russia has continued to play an integral role in, and is an integral part of, the Arctic Council, demonstrated by Russia recently assuming the Chair of the Arctic Council.

A similar demonstration of Russian commitment to cooperation rather than conflict within the region is its active participation for over 20 years in the Barents Euro-Arctic Council (BEAC), ${ }^{132}$ a forum for intergovernmental cooperation on issues concerning the Barents Region, comprising Russia (Arkhangelsk, Karelia, Komi, Murmansk and Nenets), Norway, Sweden and Finland, Iceland, and the European Commission. To date, Russia has not indicated that it seeks any changes to the cooperative nature of BEAC Russia has not indicated any change to BEAC, nor has it withdrawn support for the forum. Russia remains committed to the focus of BEAC on economic development and transport. ${ }^{133}$ Within BEAC, Russia has identified the future potential of the NSR that would benefit the Barents Region and all members of BEAC, providing economic and business opportunities to all, ${ }^{134}$ including Arctic members and the EU. Support of BEAC was demonstrated by the Russian foreign Minister Lavrov at the XV meeting, ${ }^{135}$ where Russia affirmed its commitment to BEAC:

the principle of continuity, taking into account the interests of all participants in Barents cooperation, including the indigenous population. We prioritise the promotion of the region's sustainable social and economic development, putting in place modern infrastructure and making the region more competitive and attractive to investors through the effective utilisation of its industrial, scientific, innovative, and resource potential, as well as in compliance with environmental requirements. ${ }^{136}$

The establishment of several regional bodies has contributed to cooperation and stability in the region. Previously a region of weak governance, the creation

132 See Chapter 3 as well.

133 Joint Communiqué, xv Session of the Barents Euro-Arctic Council (15 October 2015) $<$ http://formin.finland.fi/public/default.aspx? contentid=335913\&contentlan=2\& culture=e $>$ accessed 12 August 2016.

134 Ibid., art 9 .

135 <http://www.mid.ru/en/sovet-gosudarstv-barenceva/evroarkticeskogo-regiona-sber-/-/ asset_publisher/ovP3hQoCPRg5/content/id/1846132> accessed 18 August 2016.

136 Russian Ministry of Foreign Affairs, Comment by the Information and Press Department on Foreign Minister Sergey Lavrov's Participation in the 15th ministerial meeting of the Barents/Euro-Arctic Council (2015) <http://www.mid.ru/en/sovet-gosudarstv-barenceva/ evroarkticeskogo-regiona-sber-/-/asset_publisher/ovP3hQoCPRg5/content/id/1846132> accessed 16 August 2016. 
of the Arctic Council in 1996 along with the Barents Regional Council have been an innovative arrangement, leading the former Norwegian Foreign Minister to recently declare that in the Arctic there is less risk of conflicts arising from the region, but greater risk that tensions may spillover from elsewhere. ${ }^{137}$ Russian support for such a regional cooperative approach is reiterated in Article 7 (c) of the 2008 Russian Arctic Policy, enunciating that strategic Arctic priorities for the Russian Federation include strengthening cooperation with the Arctic Council and BEAC. ${ }^{138}$ This support has again been reiterated in the 2016 Foreign Policy Concept of the Russian Federation, ${ }^{139}$ with Russia recognizing the special responsibility that Arctic states bear for the sustainable development of the arctic region. ${ }^{140}$ Recognizing such responsibility, Russia also advocates enhanced cooperation in the Arctic Council and the Barents Euro-Arctic Council. ${ }^{141}$

Another strong indicator of the cooperative nature of Russian Arctic policy is its respect for the international law framework governing the Arctic Region. In 2008 the five Arctic states declared at Ilulissat that UNCLOS would be the 'governing international law' regarding the development of the Arctic. ${ }^{142}$ In particular, Russian recognition of and deference to UNCLOS includes the resolution of conflicting continental shelf claims; ${ }^{143}$ a State's right over mineral resources in the territorial sea and continental shelf, ${ }^{144}$ a State's duty to protect marine ecosystems, ${ }^{145}$ and special provisions regarding ice-covered waters of the EEZ that authorizes Arctic coastal States to enforce shipping environmental protection..$^{146}$

137 Johan Store Støre, 'Is This a New Era for the Arctic?' (World Economic Forum, 5 January 2016) <https://www.weforum.org/agenda/2016/o1/is-this-a-new-era-for-the-arctic/> accessed 19 August 2016.

1382008 Russian Arctic Policy, n. 8o, above.

139 Foreign Policy Concept of the Russian Federation (approved by President of the Russian Federation Vladimir Putin on November 30 2016) <http://www.mid.ru/en/foreign policy/official_documents/-/asset_publisher/CptICkB6BZ29/content/id/2542248> accessed 4 Feburary 2017.

140 Ibid, Article 76.

141 Ibid.

142 Illulisat Declaration, Arctic Ocean Conference (Illulisat, Greenland 27-29 May 2008) $<$ http://www.oceanlaw.org/downloads/arctic/Ilulissat_Declaration.pdf > accessed 12 February 2016.

143 Article 76, UnCLOS.

144 Article 9, UnCLOS.

145 Article 192, UNCLOS.

146 Article 234, UNCLOS. 
Russia's commitment to UNCLOS ${ }^{147}$ was demonstrated in April 2010 in the delimitation of the maritime border between Russia and Norway in the Barents Sea. After being contested by both States for almost 40 years, a cooperative approach was utilized to delimit the border in order to enable both states to pursue economic activities. The maritime delimitation, whilst a surprise to the international community, including Norway, has been interpreted as the commencement of a Russian cooperative phase regarding the Barents region and the High North. To date, there have been no actions by Russia that indicate aggression and conflict. There has been a peaceful establishment of Russian military in the Arctic Region, which has been viewed by the NIS as not posing a threat to Norway. Furthermore, in the 2016 Foreign Policy Concept of the Russian Federation, ${ }^{148}$ the Russian government reiterated its peaceful approach to the Arctic, stating that 'The Russian Federation believes that the existing international legal framework is sufficient to successfully settle any regional issues through negotiation', including the issue of defining the outer limits of the continental shelf in the Arctic Ocean. ${ }^{149}$

\section{5}

\section{Conclusion}

This paper has examined and analyzed EU and Russian Arctic policies in order to determine whether EU and Russian Arctic policies, which since 2015 has focused on the remilitarization of the Arctic, are divergent, thereby creating conflict within the region. Russia has demonstrated a respect of the international interests that govern the seas, and has engaged with the development of soft law in the region. To date, Russia has complied with all international legal instruments, and initiated the peaceful maritime delimitation of its border with Norway. It has demonstrated leadership within the Arctic Council, especially in the establishment of SAR and MOPPR, and played a leading role in BEAC. Furthermore, it has demonstrated the use of the NSR from as early as

\footnotetext{
147 Russia undertook this delimitation in accordance with Article 74 and Article 83 of the United Nation Convention on the Law of the Sea, regarding the delimitation of the EEZ and the Continental Shelf with opposite or adjacent coasts.

148 Foreign Policy Concept of the Russian Federation (approved by President of the Russian Federation Vladimir Putin on November 30 2016) <http://www.mid.ru/en/foreign policy/official_documents/-/asset_publisher/CptICkB6BZ29/content/id/2542248> accessed 4 Feburary 2017.

149 Ibid, Article 76.
} 
the 1930s, which correlates to Russia's exploitation of natural resources in the Arctic. Such strength in the Arctic was diminished in the period after the collapse of the Soviet Union, where naval bases were deactivated, military bases closed, and the region largely abandoned. However, since coming to power in 200o, Russian President Vladimir Putin has reviewed and revised the value of the Arctic. Since 2001, the Arctic has been reestablished as a priority for the Russian Federation, particularly the development of its resources and the development of the NSR. This commitment was reiterated in 2008 with the Arctic Policy, and again in July 2015 when Russia released its draft Maritime Doctrine, which reiterated the importance of the Arctic.

In reiterating the importance and value of the Arctic, areas that were previously of strong military importance, particularly Murmansk and the Kola Peninsula, are again being activated to assist in the development of the resources that EU wants to access. In particular, Murmansk is of vital importance, due to the ice-free port. Russia sees increased naval presence there vital to achieving economic growth and development. The utilization of the military on the Arctic is logical given it is the most prepared and trained for the area, demonstrated by the incorporation of the Coast Guard as a branch of the military in Norway and the Us, since only the navy can provide the essential personnel, equipment and training to conduct Arctic operations. Other commercial areas, such as around Norilsk, have always remained militarized for development, demonstrating that military capacity and infrastructure is best able to deal with this in this hostile environment.

The argument that Russian militarization of the Arctic is due to Russian aggression is fanciful, rejected by Russia's closest neighbour, Norway. Rather the evidence demonstrates that Russia is reengaging in the region, reopening and remilitarizing regions in the areas that were decommissioned at the end of the cold war, when there was little use for the regions in the post conflict era. Evidence indicates that there are no alarming trends of aggression and conflict in the Arctic, or that Russia is seeking to reverse its trend of cooperation in the region. In 2001 Russia set in motion a policy of focus on the Arctic and resourcing the Arctic, one that has been strengthened and enhanced by the 2015 Doctrine, and the maritime delineation with Norway under a 76 of the UNCLOS.

Certainly there is a focus on military activity and increased personnel in the Arctic, in part tied to agreements on SAR and OSPR. Rather, increased military activity is also tied to the use of the military to develop regional infrastructure that is needed. Such militarization clearly has made the EU and the Us nervous. However, this action has not indicated a rise in conflict in the region, or a move away from cooperation. Rather, it indicates that although there is 
conflict and tension between the EU and Russia in other regions of the world, particularly the Ukraine, there is a commonality in Russian and EU Arctic policy, which is fundamentally based upon a mutual respect for the UNCLOS. This commonality is two fold. Firstly, the EU and Russia have a commercial interest in the NSR for shipping and navigation, with an emphasis on freedom of navigation and the right of innocent passage. Secondly, natural resources are of interest to both the EU and Russia. Russia wants to secure and delineate them, and the EU wants to form long-term partnerships to secure access to them. Thus there is a commonality of Arctic policy interests between Russia and the EU, which appear to be ushering in an era of cooperation, not conflict and the threat of war. 